ラル、抗毒素ノ消失爿態 $=$ 比シ 4 倍掘ク，㕛㣻 疫输血群卜馬血清猙注群卜ノ毒素耐過力ノ比八 凡ソ $4: 1$ ナリ。

斯クシテ免疫血輸血 $=$ ヨル治潦試驗 ガ. 體重 $250 \mathrm{~g}$ 海猽二確實致死量 瑟セシメ. 1 時間後ニ之尹救ハントスルニ八輸 血ヨ以テスレパ1/15 $\mathrm{AE}=$ テ足り得べキ =璟シ. 馬血清ニテ八其倍量 $1 / 7 \mathrm{AE}$ 习靜胍內二與フル カ. 其 5 倍量 $0.35 \mathrm{AE}$ ヨ皮下=與へザルベカラ ス。 100 致死量ト云フガ如キ大量毒素ニヨル被 中毒動物二對シテモ．１時間後二行ハレタル輸 血ハ1.7AE =テ充分治療的效果 騒清静注=テ八其倍量 $3.5 \mathrm{AE} 7$ 要シ．同皮 下注射ニヨルトキハ55AE，大抗毒素量 7 必要 トシタリ。

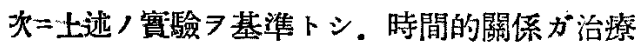
的效果 $=$ 及ボス影響 後 2 時間,ニシテ與へラレタル馬血清靜注群二ハ 始ンド治效フ奏シタルモノナキ二對シ．輸血群 八充分 =救治シ得ルノ能力

血液中/特異成分 (抗毒素) 以外ノ非特異性成 分/治療的效果 7 見タル余，實驗二於テハ、朱 ダ之ア確カムルコト能ハザリキ。文抗毒素习含 有七ザル正常血液，輸血八何等治療的，働キ 有セザルョ見タリ。份木抗毒素含有血液卜雖 モ. 之 7 皮下 =與フ儿時八其治效八同單位，哭 血清皮下注射卜大差ナク．楯血スルコトニヨリ テ初メテ特殊效果

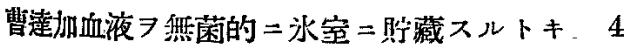
週間後えヨ检シタルモ其抗毒單位二變化ナカリ *。

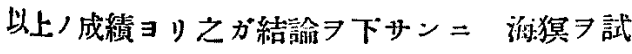

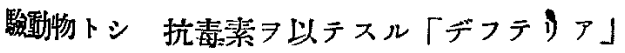

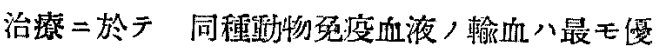
秀ナル效果ヨ示シ.抗毒婜血洂，静注之二次ギ. 其皮下注射法八前二者二比シ遙カ二劣レリ。眔

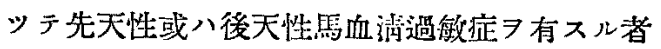
=㻗スル婜血清再注射，危險八其靜注 大トシ．次ブ䈷肉內及ビ皮下注射，順トナルベ シ。而シテ同種動物間，輸血八其血液型ニシテ 適合セルモノナラバ殆ンド危險ナキ八周知，事 ナリ。

故二点血清二啟感ナル者，治療二八炛度血液， 輸血ガ危險ナクシテ然モ卓越セル治效ア奏スル 最モ理想的ノ療法トシテ推獎シ得べキモノト考 ヘラル。況ンサFormovaccin 7 以テ人體二总

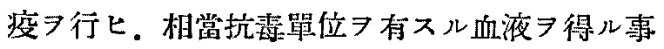
，比較的容易 シシテ，且ッ輸血用血液，凝圆

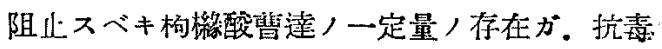

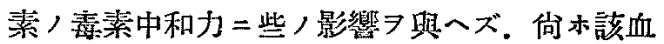
液, 数僴間二亘几保存八何等其能力二變化 7 來 タサ・ル事ヨ立證シ得タルニ於テラヤ。而シテ 苼疫血液輸血ノ斯クノ如キ格段ナ儿效果 7 呈ス 儿理由八輸血用血液卜踓モ，其皮下注射力效果

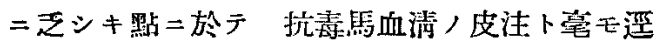

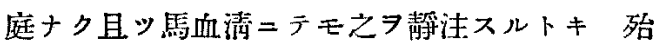
ンド輸血二近キ成繢ヨ示セルニッ, 事實二爁ル 時. 只單二同種助物免疫血液 7 與へタルガ第 メナリト解䆁スルョリモ。蜜口危險习件ハザル 最理想的狀態 =於テ抗表素が直接血中二注入セ ラレタル結果ナリト斷定スルヨ至虽ナリトセン 乎。

\section{類題 3.口蓋扁䖴腺內二於ケル} 「ヂフテリー菌ニ就テノ硏 究 大野勤次郎(骨活大) 口惪扁桃腺內二於少ル「デフラリー」菌二就 


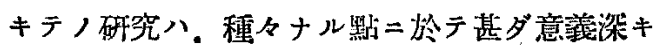

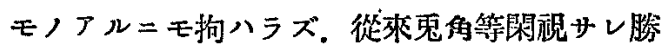
チンシテ そニ就キテノ報告ヨ見ルモ殊二其检 查方法等ニ於テ不借ナル點多々アルラ知儿。茲 =於テ余八昭和11年 1 月以來田中敎授指導，下 二本研究フ企圖シ．先ヅ「ヂフテリー」二羅蚛 ノ經驗 7 有ス几者 13 例二對シ。扁恌腚ノ全摘 出ヨ行ヒ（內 2 例ハ「デフテリー」再發患者二 シテ 米ダ临膜，存在セル內=手術セシモノナ ルモ。他ノ 11 例八敦レモ「デフテリー」，全

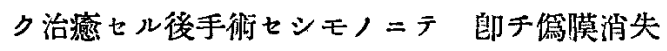
後夫々 11 日，19日，21日，49 日，3 ケ月， 6 ケ月. 8 ケ月. 1 年. 1 年 5 ケ月. 8 年及ビ 9 年 ア經過シ，且ツ又敦レモ術前ノ檢查ニテハ咽頭 表面. 鼻腔等ニ「ヂフテリー」菌习證明セザリ シモノナリ). 之等摘出 $=ヨ$ リ得々ル扁挑腺二就 キテ. 特二能フ限り多数ノ腺窩フ開放露出シテ 之ア检查スルコトニ努メッ、極メテ熱心 =「デ フテリー菌ノ检案フ行ヒタル結果. 内 11 例郎 チ $84.6 \%$ ，高率=於テ「デフテリー」荄楻菌， 分離二成功セリ。ヨツテ等 11 菌秼二就キテ更 $=$ 詳細二其細菌學的謵性狀（菌)形態排列. 極 小體發現狀態. グラム固着性. 䜠種培養基上=

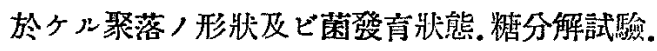
種種水素「イオン」漂度異ニスル「ブィョン」

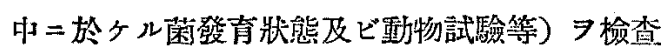
セシ結果。 之等八敦レモ其生物學的諸性狀ヨリ シテ，售性「ヂフテリー」菌認ム可キモノナ ルタ知レリ。ヨッテ余八更ニ「デフテリー」= 羅患セル䅔驗习有セザルモ，70名二就キテモ 同樣ナル检查 $コ$ 施行セジ.内 22 名即チ 431.4 $\%=$ 於テ其扁桃腺队部二魚性「デフテリー」囷 卜認ム可キモノ替秋セシメオルラ確カメタ
1).

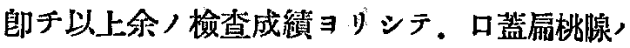
之ヨ誹細二調查セバ．從來考へラレタルョリュ 遥カ二多數ノモノ=於テ其內部二直性「デつ; リー」菌习潜伏セシメオルモノニシテ.殊ニー 度「デフテリー」=蜼勨セルモノ＝於テい，其入

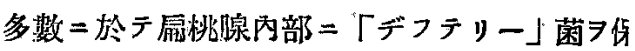
有スルモノナルラ知り得可シ。此事實八實 $=$ 年

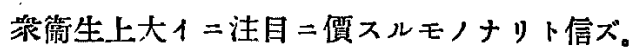
管ツテGood八屚桃腺內二存在ス认細菌八奎 身免度二關係詴スルモノナリトノ說习稃へ。

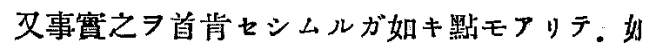
斯キ說モ單ナル臆說トシテ一笑二附シ得ザルモ ノナラント思考セラル、モ。斯カル生理的作厈 ，有無二拘ハラズ，之等扇桃腺內二潜在ス几 「ヂフテリー」菌ノ傳染源トシテノ意義八亦湆 シテ看過シ得ザルモノナリ。殊に嘗ツテ「ヂ テリー」二踓患セル經駿す有スルモノニ對シラ 八. 其菌陽性率ノ極メテ高度ナルノミナラズ. 其保有菌ノ毒性 7 保持七几モノ多キ二鑑 $\mathbf{i}$. 特 ニ充分ナル注意，警找ノ必要フルタ思フモノナ リ。

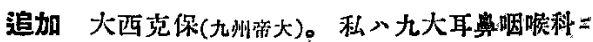

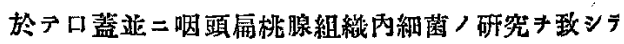
居りマスカ゚. 方法トシマシテ「パタフィン」包瑟得 5 山曆せ二切片キ作り．「リチォン・カルミンニ クトタアブラウ」重染色キナシ检䚄シテ居りマフ。

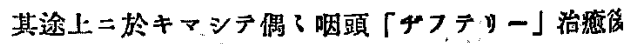

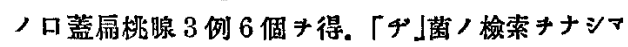

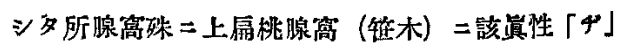

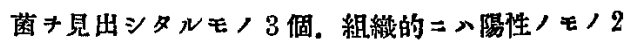
個キ得マシタ。

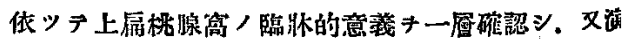

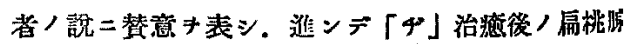

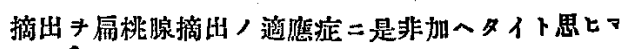
‥ 